\title{
Chemical Synthesis and Cytotoxicity of Dihydroxylated Cyclopentenone Analogues of Neocarzinostatin Chromophore
}

\author{
Michael D. Urbaniak, ${ }^{\mathrm{a}}$ Lisa M. Frost, ${ }^{\mathrm{a}}$ John P. Bingham, ${ }^{\mathrm{b}}$ Lloyd R. Kelland, ${ }^{\mathrm{c}}$ \\ John A. Hartley, ${ }^{\mathrm{b}}$ Derek N. Woolfson ${ }^{\mathrm{d}}$ and Stephen Caddick ${ }^{\mathrm{a}, *}$ \\ ${ }^{a}$ Center for Biomolecular Design and Drug Development, School of Chemistry, University of Sussex, Falmer, Brighton BN1 9QJ, UK \\ ${ }^{\mathrm{b}}$ Cancer Research UK Drug-DNA Interactions Research Group, Department of Oncology, University College London, \\ London WIW $7 B S$, UK \\ ${ }^{\mathrm{c}}$ Department of Bioscience, St. Georges Hospital Medical School, Cranmer Terrace, London, SW17 OQS, UK \\ ${ }^{\mathrm{d} C e n t e r ~ f o r ~ B i o m o l e c u l a r ~ D e s i g n ~ a n d ~ D r u g ~ D e v e l o p m e n t, ~ S c h o o l ~ o f ~ B i o l o g i c a l ~ S c i e n c e s, ~ U n i v e r s i t y ~ o f ~ S u s s e x, ~ F a l m e r, ~}$ \\ Brighton BN1 9QJ, UK
}

Received 8 January 2003; revised 26 February 2003; accepted 17 March 2003

\begin{abstract}
Compounds containing the naphthoate moiety of Neocarzinostatin chromophore or 2-hydroxynaphthoate have been synthesized and evaluated for cytotoxic activity against a leukemia cell line and a small panel of human-tumor cell lines. Those compounds containing a cyclopentenone moiety were active, with the carbonyl group being essential for biological activity.

(C) 2003 Elsevier Science Ltd. All rights reserved.
\end{abstract}

Neocarzinostatin (NCS), an antitumour antibiotic isolated from Streptomyces carzinostaticus, has found clinical application in Japan against leukemia and cancers of the bladder, stomach, pancreas, liver and brain. ${ }^{1,2}$ NCS comprises a highly reactive enediyne chromophore (1) non-covalently bound to an $11 \mathrm{kDa}$ protein (apoNCS). The cytotoxic activity of NCS results from cycloaromatization of the 9-membered enediyne ring of $1,{ }^{3}$ which produces a di-radical species that targets DNA. Minor-groove binding and intercalation of the naphthoate moiety (2) position the di-radical species such that hydrogen abstraction occurs from the deoxyribose sugar backbone, which leads to single and double stranded cleavage. ${ }^{4}$

Significant practical difficulties are associated with the design of analogues of $\mathbf{1}$. NCS chromophore is difficult to synthesize and handle; hence analogues incorporating the 9-membered enediyne are potentially also hard to prepare and manipulate. Because of such difficulties we propose that the naphthoate portion of 1 could be used as a synthetic base for the design of new cytotoxic entities that would be simpler to prepare and more stable

*Corresponding author. Tel./fax: +44-1273-678734; e-mail: s.caddick@ sussex.ac.uk than enediyne containing analogues of $1 .^{5}$ Here we report a new class of analogues of NCS that retain a naphthoate component, but are devoid of the enediyne motif. Our findings indicate that simple cyclopentenone derivatives incorporating a naphthoate moiety exhibit significant cytotoxic activity against cultured human cell lines. The results obtained for $\mathbf{5 a}, \mathbf{5 b}$ and $\mathbf{5 c}$ compare favourably with the activity shown for the clinically used anti-cancer drug Melphalan.

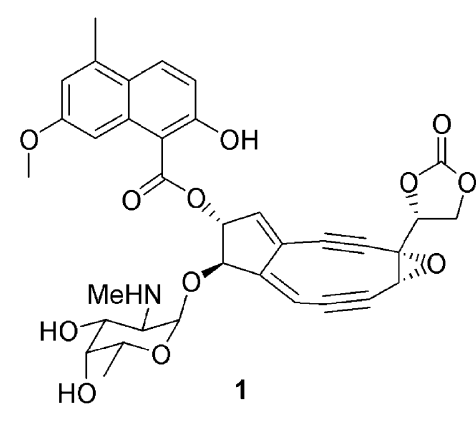<smiles>COC(=O)c1c(O)ccc2c(C)cc(OC)cc12</smiles>

Dicyclohexyl carbodiimide (DCC) coupling was used to prepare a series of esters incorporating either the NCS naphthoate $\mathbf{2}$ or the readily available 2-hydroxy-naph- 
thoic acid (3) from $\mathbf{4 a}$ or $\mathbf{4 b}$, (Scheme 1). ${ }^{6-9}$ Protectinggroup manipulation afforded both regio-isomers, whilst Luche-type reduction of the conjugated carbonyl group afforded an analogous set of dihydroxy cyclopentenes. The latter, which lack the enone functionality, are poor electrophiles/alkylators and are anticipated to show negligible cytotoxic action. A subset of compounds was also made with bromine alpha to the carbonyl, increasing the electrophilicity of the cyclopentenones and hence their potential activity.

All compounds were tested for in vitro cytotoxic activity against the human leukemic cell line K562 (Table 1). ${ }^{10}$ As anticipated, dihydroxylated cyclopentenes were found to be inactive at the concentrations used. The cyclopentenones showed activity at micro-molar concentrations, demonstrating that the carbonyl group was required for cytotoxic activity. However, the presence of bromine alpha to the carbonyl had little affect on the potency of these compounds. Otherwise, no significant structure-activity trend was seen for the regioisomers, or the identity of the naphthoate moiety with this cell line.

The active compounds were then screened against a small panel of human-tumor cell lines \{A2780, A2780CisR, CH1, SKOV-3 (ovarian) and HT29 (colon)\}, (Table 2). ${ }^{11}$ Differences in the activity of compounds not previously apparent were noted in this

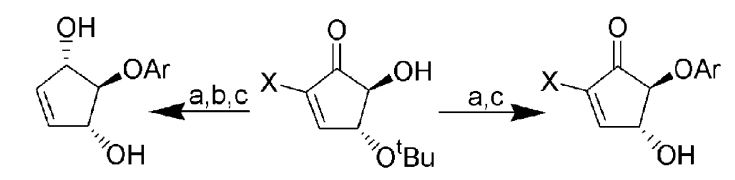

$\begin{array}{lll}\mathbf{6 a} \mathrm{Ar}=\mathbf{2}, 22 \% & \mathbf{4 a} X=\mathrm{H} & \mathbf{5 a A r}=\mathbf{2}, X=H, 55 \% \\ \mathbf{6 b} \mathrm{Ar}=\mathbf{3}, 20 \% & \mathbf{4 b} X=\mathrm{Br} & \mathbf{5 b} \mathrm{Ar}=\mathbf{3}, \mathrm{X}=\mathrm{H}, 66 \% \\ & & \mathbf{5 c A r}=\mathbf{3}, \mathrm{X}=\mathrm{Br}, 31 \%\end{array}$

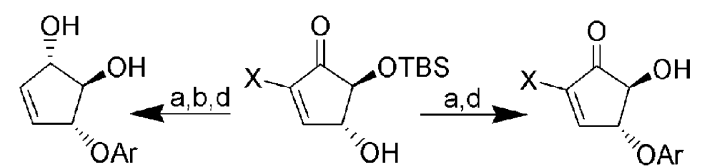

9a $\mathrm{Ar}=\mathbf{2}, 10 \% \quad \mathbf{7 a} \mathrm{X}=\mathrm{H}$

$9 \mathrm{~b} \mathrm{Ar}=\mathbf{3}, 32 \% \quad \mathbf{7 b} \mathrm{X}=\mathrm{Br}$

8a $\mathrm{Ar}=\mathbf{2}, \mathrm{X}=\mathrm{H}, 15 \%$

8 b $\mathrm{Ar}=3, \mathrm{X}=\mathrm{H}, 30 \%$

8c $\mathrm{Ar}=3, \mathrm{X}=\mathrm{Br}, 17 \%$

Scheme 1. Synthesis of naphthoate esters. (a) DCC, $\mathrm{ArCO}_{2} \mathrm{H}, \mathrm{THF} /$ DCM 1:1, $0^{\circ} \mathrm{C}$; (b) $\mathrm{CeCl}_{3} .7 \mathrm{H}_{2} \mathrm{O}, \mathrm{NaBH}_{4}, \mathrm{CH}_{2} \mathrm{Cl}_{2}, 0^{\circ} \mathrm{C}$; (c) $\mathrm{TiCl}_{4}$, $\mathrm{CH}_{2} \mathrm{Cl}_{2}, 0^{\circ} \mathrm{C}$; (d) tert-Butyl-ammonium fluoride, $\mathrm{CH}_{2} \mathrm{Cl}_{2}, 0^{\circ} \mathrm{C}$.

Table 1. Cytotoxicity of compounds against leukemic cell line K562

\begin{tabular}{lccc}
\hline Compd & $\begin{array}{c}\text { Cytotoxicity } \\
\mathrm{IC}_{50}, \mu \mathrm{M}^{\mathrm{a}}\end{array}$ & Compd & $\begin{array}{c}\text { Cytotoxicity } \\
\mathrm{IC}_{50}, \mu \mathrm{M}^{\mathrm{a}}\end{array}$ \\
\hline $\mathbf{5 a}$ & $4.5 \pm 1.5$ & $\mathbf{8 a}$ & $5.0 \pm 1.0$ \\
$\mathbf{5 b}$ & $4.0 \pm 2.0$ & $\mathbf{8 b}$ & $6.0 \pm 1.0$ \\
$\mathbf{5 c}$ & $5.0 \pm 2.0$ & $\mathbf{8 c}$ & $3.5 \pm 2.5$ \\
$\mathbf{6 a}$ & $>100$ & $\mathbf{9 a}$ & $>100$ \\
$\mathbf{6 b}$ & $>100$ & $\mathbf{9 b}$ & $>100$ \\
Melphalan & $30 \pm 4$ & & \\
\hline
\end{tabular}

${ }^{\mathrm{a}} 1 \mathrm{~h}$ Incubation. Values are means of three experiments, standard deviation is given.
Table 2. Cytotoxicity of compounds against a small cell line panel

\begin{tabular}{lccccc}
\hline Compd & \multicolumn{5}{c}{ Cytotoxic activity a against } \\
\cline { 2 - 6 } & A2780 & A2780CisR & CH1 & SKOV-3 & HT29 \\
\hline $\mathbf{5 a}$ & 9.4 & 9.0 & 11.0 & 7.2 & 13.0 \\
$\mathbf{5 b}$ & 3.7 & 9.4 & 5.8 & 3.1 & 12.0 \\
$\mathbf{5 c}$ & 9.4 & 13.0 & 11.0 & 9.4 & $>25$ \\
$\mathbf{8 a}$ & 2.5 & 4.0 & 2.5 & 2.5 & 11.0 \\
$\mathbf{8 b}$ & 2.7 & 8.6 & 4.0 & 2.3 & 12.0 \\
$\mathbf{8 c}$ & 10.0 & 17.5 & 11.0 & 11.0 & $>25$ \\
\hline
\end{tabular}

a96 h Incubation, $\mathrm{IC}_{50}(\mu \mathrm{M})$ values.

screen. Firstly, the brominated compounds $\mathbf{5 c}$ and $\mathbf{8 c}$ were found to be less active than the simple enones $\mathbf{5 b}$ and $\mathbf{8 b}$ respectively. Secondly the $4^{\prime}$ regioisomers $\mathbf{8 a}-\mathbf{b}$ were more active than the $5^{\prime}$ regio-isomers $\mathbf{5 a}-\mathbf{b}$, most noticeably when the aromatic substituent was $\mathbf{2}$. Interestingly, comparison of the potency of analogues against the cell lines A2780 and A2780CisR, the latter possessing 15 -fold resistance to cisplatin, showed that the level of resistance was reduced, and in some cases almost completely circumvented (e.g., 5a, 5c, 8a). The potency of the compounds also varied between different cell lines, suggesting that structural features of the compounds have the potential to discriminate between cell types.

In conclusion, we have demonstrated that simple naphthoate-derived analogues of NCS chromophore, which contain a cyclopentenone, possess cytotoxic activity in the micro-molar range against a leukemia cell line and a small panel of human-tumor cells. These data demonstrate that this type of NCS chromophore analogue has sufficient potency to be of potential therapeutic interest. Such species offer considerable advantages, as they are easy to prepare and handle. Studies directed towards determining the mode of biological action of these analogues are underway.

\section{Acknowledgements}

We are grateful to Cancer Research UK, EPSRC, BBSRC, AICR, AstraZeneca, GlaxoSmithKline, Novartis and the Centre for Biomolecular Design and Drug Development at the University of Sussex for supporting our programme.

\section{References and Notes}

1. Ishida, N.; Miyuzaki, K.; Kumagai, K.; Rikimaru, M. J. Antibiot. 1965, 18, 68.

2. Maeda, H.; Edo, K.; Ishida, N. In Neocarzinostatin: The Past, Present and Future of an Anticancer Drug; Springer-Verlag: Tokoyo, 1997, p 287.

3. Myers, A. G. Tetrahedron Lett. 1987, 28, 4493.

4. Gao, X.; Stassinopoulos, A.; Rice, J. S.; Goldberg, I. H. Biochemistry 1995, 34, 40.

5. Hodgkinson, T. J.; Kelland, L. R.; Shipman, M.; Suzenet, F. Bioorg. Med. Chem. Lett. 2000, 10, 239.

6. Caddick, S.; Khan, S. J. Chem. Soc., Chem. Comm. 1995, 19, 1971. 
7. Caddick, S.; Khan, S.; Frost, L. M.; Smith, N. J.; Cheung, S.; Pairaudeau, G. Tetrahedron 2000, 56, 8953.

8. Caddick, S.; Cheung, S.; Doyle, V. E.; Frost, L. M.; Soscia, M. G.; Delisser, V. M.; Williams, M. R.; Etheridge, Z. C.; Khan, S.; Hitchcock, P. B.; Pairaudeu, G.; Vile, S. Tetrahedron 2001, 57, 6295.

9. Urbaniak, M. D.; Muskett, F. W.; Finucane, M. D.; Caddick, S.; Woolfson, D. N. Biochemistry 2002, 41, 11731.

10. Cytotoxicity assay: $200 \mu \mathrm{L}$ of K 562 cells $\left(5 \times 10^{4}\right.$ cells $\left./ \mathrm{mL}\right)$ were aliquoted into 96-well microtitre plate and incubated for $1 \mathrm{~h}$ with the test compound $(100 \mu \mathrm{M}$ to $30 \mathrm{nM})$. After washing, the cells were incubated for a further four days before the number of viable cells was counted using the MTT assay. For a description of the MTT assay see: Alloy, M. C.; Scudiero, D. A.; Monks, A.; Hursey, M. L.; Czerwinski, M. J.; Fine, D. L.; Abbott, B. J.; Mayo, J. G.; Shoemaker, R. H.; Boyd, M. R. Cancer Res. 1988, 48, 589.

11. Cytotoxicity assay: Cells were added to 96-well microtitre plates $\left(5 \times 10^{4}\right.$ cells $\left./ \mathrm{mL}\right)$ and allowed to attach overnight. Test compounds $(100 \mu \mathrm{M}$ to $2.5 \mathrm{nM})$ were incubated with the cells for $96 \mathrm{~h}$, then the number of cells was counted using the Sulforhodamine B (SRB) assay. For a description of the SRB assay see: Skehan, P.; Storeng, R.; Scudiero, D.; Monks, A.; McMahon, J.; Vistica, D.; Warren, J.; Bokesh, H.; Kennedy, S.; Boyd, M. R. J. Nat. Cancer Inst. 1990, 82, 1107. 